IZA DP No. 7111

Returning Home at Times of Trouble?

Return Migration of EU Enlargement Migrants during the Crisis

Anzelika Zaiceva

Klaus F. Zimmermann

December 2012 


\title{
Returning Home at Times of Trouble? Return Migration of EU Enlargement Migrants during the Crisis
}

\author{
Anzelika Zaiceva \\ University of Modena and Reggio Emilia and IZA \\ Klaus F. Zimmermann \\ IZA and Bonn University
}

Discussion Paper No. 7111
December 2012

\author{
IZA \\ P.O. Box 7240 \\ 53072 Bonn \\ Germany \\ Phone: +49-228-3894-0 \\ Fax: +49-228-3894-180 \\ E-mail: iza@iza.org
}

\begin{abstract}
Any opinions expressed here are those of the author(s) and not those of IZA. Research published in this series may include views on policy, but the institute itself takes no institutional policy positions. The IZA research network is committed to the IZA Guiding Principles of Research Integrity.

The Institute for the Study of Labor (IZA) in Bonn is a local and virtual international research center and a place of communication between science, politics and business. IZA is an independent nonprofit organization supported by Deutsche Post Foundation. The center is associated with the University of Bonn and offers a stimulating research environment through its international network, workshops and conferences, data service, project support, research visits and doctoral program. IZA engages in (i) original and internationally competitive research in all fields of labor economics, (ii) development of policy concepts, and (iii) dissemination of research results and concepts to the interested public.
\end{abstract}

IZA Discussion Papers often represent preliminary work and are circulated to encourage discussion. Citation of such a paper should account for its provisional character. A revised version may be available directly from the author. 


\section{ABSTRACT}

\section{Returning Home at Times of Trouble? Return Migration of EU Enlargement Migrants during the Crisis*}

The eastern enlargements of the EU in 2004 and 2007 have stimulated the mobility of workers from the new EU8 and EU2 countries. A significant proportion of these migrants stayed abroad only temporarily, and the Great recession may have triggered return intentions. However, a return may be postponed if the economic situation in a sending region is persistently worse. This paper documents emerging evidence on return migration in postenlargement Europe combining several data sources to describe the characteristics and selection of the returnees, as well as the determinants of return migration and potential remigration decisions. The findings suggest that brain circulation rather than brain drain is relevant for several new member states and that returnees are most likely to migrate again. Moreover, the proportion of potential movers is larger in countries most affected by the crisis. Repeat and circular migration is expected to alleviate the potential negative impacts of the crisis, leading to a more efficient allocation of resources within the enlarged EU.

\section{JEL Classification: F22, J61}

Keywords: return migration, EU Eastern enlargement, economic crisis

Corresponding author:

Klaus F. Zimmermann

IZA

P.O. Box 7240

53072 Bonn

Germany

E-mail: Zimmermann@iza.org

\footnotetext{
* We are grateful to the participants of the 5th IZA/CEUR Workshop on "EU Enlargement and the Labor Markets: Migration, Crisis and Adjustment in an Enlarged E(M)U II" for helpful comments.
} 


\section{Introduction}

Eastern enlargements of the European Union to eight Central and Eastern European countries (EU8) together with Cyprus and Malta in 2004 and to Romania and Bulgaria (EU2) in 2007 were unprecedented in many aspects. Leaving aside Cyprus and Malta, the large population size of the acceding block and substantial income differentials between the old and the new EU members generated fears of a huge influx of Central and Eastern European migrants who would settle permanently in the old EU15 countries, leading to benefits shopping and negative impacts on the receiving countries' labour markets. ${ }^{1}$ However, a significant proportion of these migrants considered and indeed stayed abroad only temporarily (Polard et al., 2008; European Commission, 2008; Eurofound, 2012). Overall, after the enlargements, immigration from the EU8 and EU2 has increased the EU15 population by approximately 1\%, with around $1.8 \%$ and $4.1 \%$ of the respective regions’ population having moved into the EU15 (Holland et al., 2011; Brücker and Damelang, 2009).

The recent economic crisis and a deterioration of the economic situation in many receiving countries suggest a possible slowdown in migration flows from the new EU members, and an increase in return migration or so-called accelerated returns, when return occurs earlier than planned. However, the economic crisis has affected both receiving and sending countries, and several countries of origin were hit harder than the destination ones. For example, while the unemployment rate was over 20\% in Spain and 14\% in Ireland in 2011, it was 8\% in the UK and around 6\% in Germany. On the other hand, unemployment reached double-digit figures in Bulgaria, Hungary, Slovakia and Estonia in 2011, was close to 10\% in Poland and over 15\% in Latvia and Lithuania. Consequently, if the conditions at home are persistently worse than those in the destination, return migration may be delayed. Thus, the return migration of post-enlargement migrants is becoming an increasingly important issue, and this chapter sheds more light on it.

In general, migrants are usually highly responsive to economic cycles and act as "buffers" in the labour markets. In "good times", they solve the excess labour demand problem in host countries by filling the available vacancies and contribute to ease the inflationary pressures; they also efficiently relief sending countries' labour markets of excess labour, and help to alleviate unemployment problems and raise wages. In times of trouble, they return to their countries of origin or move onward to other destinations where work is available. In general, repeat or circular

\footnotetext{
${ }^{1}$ See, for example, Holland et al. (2011), Kahanec and Zimmermann (2010) and Kahanec, Zaiceva and Zimmermann (2010) for the study of post-enlargement migration and its impacts.
} 
migration leads to a triple-win situation as both countries of origin and destination gain from highly flexible migration, likewise the migrants themselves also gain. ${ }^{2}$

Return migration is usually beneficial for the home countries, as returnees bring new skills and competences, increase the overall human capital, and enhance productivity and employment. Such "brain-gain" or "brain circulation" counter-acts the negative "brain-drain" effects of the emigration of highly skilled individuals, and are expected to generate positive effects for the country of origin's labour markets and overall growth prospects, including indirectly via the socalled "incentive" effect, raising the average schooling of stayers in the home country. Sending countries also benefit from remittances, particularly from temporary migrants who plan to return. Finally, through network effects return (and repeat) migration may enhance trade and investment with host countries, especially in the case of skilled migration. In addition, migration policies are extremely important, and the less restrictive they are the more likely migrants are to engage in return and circular migration (Constant and Zimmermann, 2011).

Theoretical models of return migration postulate that if migration is temporary, the decision to move will not only be based on immediate and future incomes in the destination, but also on the expected future returns in the country of origin. The main motives for return include preference for consumption in the home country, family and other networks at home, taking advantage of differences in relative prices between host and home countries (high wages abroad and low prices at home), and the possibility of accumulating human capital abroad, the returns to which are higher at home. A return move is also realized when any pre-defined objectives are achieved, such as completing education or accumulating a certain amount of wealth.

A crucial issue in this context is the selection of returnees, or rather the double selection in the decisions to first migrate and then to come back, since any impact on the country of origin will generally depend on returnees' characteristics. Developing an OLG model for the decisions to migrate, return and invest in schooling, Mayr and Peri (2009) simulate it for the East-West case, predicting that if all returnees in the home country receive the same skill premium for having been abroad they will be negatively selected (but still have intermediate education, given that migrants are usually positively selected on education); however, if the skill premium increases upon return with the level of education, only the most educated will return. The aforementioned "incentive" effect combined with the fact that some highly educated migrants return and other potential migrants end up staying in the East would offset the negative effect of brain-drain accordingly.

Regarding post-enlargement migrants, some may prefer to return home due to economic reasons (for example, job loss, as many of them were employed in the sectors most affected by the

\footnotetext{
${ }^{2}$ See Constant, Nottmeyer and Zimmermann (2012) for an analysis of costs and benefits of circular migration.
} 
crisis), other - due to initially temporary intentions of staying abroad, or emerging social pressures fuelled by economic difficulties in some destination countries. In addition, highly qualified individuals may find it easier to find adequate jobs at home. Moreover, as most of these migrants were overrepresented in sectors and jobs below their qualifications, such workers may prefer returning home and working in jobs that match their qualifications. Finally, with the exceptions of Bulgaria and Romania, no restrictions on movement exist for these migrants, ${ }^{3}$ making a potential repeat move a feasible and certain future option and thus enhancing the return. However, on the other hand, the worsening economic situation at home is an important push factor that may prevent the return. In addition, established networks abroad and improved language may also act as returndeterring factors. Indeed, anecdotal evidence and mass media in some new member states suggest a decrease in return migration in recent years, and rather a "highest ever emigration”. Overall, EastWest migration flows are likely to continue in the future, yet their composition may change.

The remainder of this chapter is organized as follows. Section 2 reviews existing studies on return migration in the new EU member states. Section 3 presents an attempt to measure the return migration in the post-enlargement Europe. Characteristics of returnees, their selection patterns and determinants of return migration are analysed in Section 4, and section 5 outlines potential future East-West migration by investigating the migration intentions of both return migrants and stayers in the new EU member states. Finally, Section 6 presents some concluding remarks.

\section{Return post-enlargement migration: empirical studies}

Return migration in Central and Eastern Europe is a relatively recent phenomenon, and as such has attracted increasing academic and policy attention, particularly in the last few years. Iara (2008) and Martin and Radu (2009) are probably the first systematic cross-country studies of return migration in Eastern Europe (however, the former focuses only on young men in 2003). Martin and Radu (2009) employ the European Social Survey data for 2006 to document shares of return migrants in the Czech Republic, Hungary, Latvia, Poland, Romania and Slovakia. They furthermore use EU Labour Force Survey (LFS) data for Poland, Hungary, Latvia, Lithuania and Romania for 2002-2007 to investigate the characteristics and performance of the return migrants. Returnees in

\footnotetext{
3 Transitional arrangements that limited workers' mobility were initially introduced for a period of $2+3+2$ years for workers from the EU8 countries. In 2004, only the UK, Ireland and Sweden opened up their labour markets completely. In 2011, Germany and Austria removed the remaining restrictions for workers from the EU8 countries. Similar transitional arrangements were also imposed for workers from Bulgaria and Romania in 2007. Currently, Austria, Germany, Belgium, France, Luxembourg, Malta, Netherlands and the UK continue to apply restrictions for the EU2 workers, while Spain unprecedentedly re-introduced restrictions in July 2011 “due to serious disturbances on its labour market".
} 
their study are defined as individuals who were born in the country of their current residence but resided abroad the year before the survey, thus only capturing recent returns. The proportion of returnees was found to be the largest in Poland (7.97\%) and smallest in Hungary (2.61\%). Regarding characteristics, consistent with theoretical literature and empirical studies of return migration for other countries, they find that returnees are predominantly male, young, not married, and with a medium or high level of education, thus suggesting a positive selection on education (not in Romania). Their estimated income premium for returnees ranges from 10 to 30\%, and some evidence for negative selection on unobservables for returnees was also found. Finally, returnees were estimated to participate less in the labour market and to switch to self-employment, however, these results were not robust to the estimation method employed.

Two recent reports focus on return migration in the post-enlargement Europe. Eurofound (2012) studies the impact of the recent return migration in the EU, providing case studies for Hungary, Latvia, Poland and Romania. Despite the major difficulty in measuring return migration, as no comparable data across countries exists due to different data collection methods and definitions (stocks vs. flows, age range of migrants, time spent abroad etc.) ${ }^{4}$, the authors summarise evidence from several existing studies as well as from their own estimates, concluding that no mass return migration took place during the recent crisis. Indeed, as is also mentioned in Holland et al (2011) and Koehler et al (2010), since the economic situation in home countries also deteriorated during the crisis, emigration rates from the destination countries did not "rocket" as migrants have rather adopted a so-called "wait-and-see" strategy. Judging from the increased outflows from some destination countries, the crisis has accelerated planned returns, if anything, as some of them took place earlier than planned, as well as the likely onward migration of EU8 and EU2 migrants, but also growth in emigration from the EU8 and EU2 countries (Koehler et al., 2010; Eurofound, 2012). There was also some heterogeneity across countries: emigration slowed down in Poland and Romania, and return and circular moves increased, emigration has increased and return migration diminished in Latvia, while the impact of the crisis was minor in Hungary. Regarding characteristics, returnees are mid-age (under 45), single, male, and employed in low-skilled jobs abroad, including those with higher education (ibid), thus suggesting that overqualified individuals prefer to come back, and pointing towards the potential danger of brain-waste. Case studies also suggest that the most important return deterring factors are higher incomes abroad, access to unemployment and other benefits, and the higher probability of finding a job abroad, while family

\footnotetext{
${ }^{4}$ An example from the Eurofound (2012) is quite instructive. The authors show that even within one country estimates may diverge substantially, as is the case for Poland where the estimated return migration ranges from 39,000 (only 2009, ONS, APS) or 49,000 (2004-2010, CSO, population registers) to 500,000 (2004-2010, Fuller et al); and from 1.05 million (1989-2008, CSO, LFS) to 2.9 million (1998-2007, PORC survey).
} 
reasons were named as the main motivation for return (either to join family left behind, or with family as a tied-mover or due to a child's education). In addition, the improving economic situation at home, social networks that facilitate job finding, better career opportunities at home, in particular working according to one's qualification and positive public perceptions also facilitate return. Finally, many returnees did not rule out the possibility of repeat emigration and a significant proportion considered repeated periods of work abroad possible in the future (Eurofound, 2012), pointing towards a potential circular nature of future East-West migration.

The second report, Re-Turn (2012), is based on case studies of return migration for Czech Republic, Hungary, Poland, Slovenia and Slovakia (as well as Austria, Germany and Italy). The authors document that while returnees constitute a majority among all immigrants in Poland, it is non-nationals who immigrate most in other new member states, thus importantly suggesting that EU8 countries are becoming new immigration countries. To document characteristics of the returnees, the authors employ the EU LFS data for 2005-2008, showing that recent returnees (as above, those who resided abroad one year before the survey) are younger and positively selected in terms of education, compared to stayers and migrants. However, they are also more often unemployed and have a higher probability of not participating in the labour market. As in Martin and Radu (2009), this result may be due to the fact that only recent returnees are included in their analysis, for whom the probability of finding a job during one year may be lower. If employed, returnees are more likely to work in the service sector (apart for Poland). The authors also document that returnees do not lose connection with their home country while abroad, which may help them to re-integrate upon return. Interestingly, the majority of returnees in Poland state that work abroad has not changed their career path or even enhanced its fragmentation, and only $8 \%$ report being able to enhance their career upon return; however, the majority among returnees with tertiary education did make use of their experience abroad (Vavreckova, 2009 and GrabowskaLusinska, 2010 both mentioned in Re-Turn, 2012).

A number of studies have examined recent return migration in a single country context. For example, using the LFS data, Hazans (2008) provides econometric analysis of the return migration premium for Latvian returnees, and as part of their study, Hazans and Philips (2011) analyse returnees in Estonia, Latvia and Lithuania. Hazans (2008) finds a significant earnings premium for returnees in Latvia after having controlled for demographic characteristics, human capital and experience abroad, which is larger for men than women (more than $20 \%$ vs. $6 \%$ ). He also shows that this earnings premium is caused by foreign work experience. Hazans and Philips (2011) document that most migrants in the Baltics return within the first two years, with more than half of Latvian movers coming back within a year. The intended duration of further stay abroad increases 
with the time spent there. The authors also find higher inactivity and unemployment among returnees than stayers, arguing that this is not necessarily related to their weak labour market performance, but rather may reflect that returnees can afford to search longer due to accumulated savings, or may simply plan to work abroad again and take no job at home. Comparing the characteristics of migrants, stayers and returnees, the authors show that returnees are more educated than migrants (and stayers in Latvia), work in more skilled occupations than migrants but less skilled than stayers, are less frequently overqualified for their jobs than migrants, and have higher incidence of temporary and short-term contracts than stayers, which is however lower than for current migrants. Pungas et al. (2012) analyse return intentions of Estonian migrants in Finland, showing that those who work below their qualifications have a higher tendency to return. Barcevicius and Zvalionyte (2012) provide a comprehensive study of return migration in Lithuania, based on data analysis, case studies and interviews. The authors show that family and cultural motives are most important for return decisions and that work experience abroad is beneficial for those who worked according to their qualifications - along with those who received a degree abroad they have higher earnings upon return. The authors also document a very high incidence of repeat emigration with $25 \%$ of the Lithuanian respondents with migration experience showing "firm" intentions to move again. Grabowska-Lusinska (2010) studies returnees in Poland and shows that the largest share of returnees is from Germany, while the shares of emigrants are the largest for the UK and Germany. Returnees are mainly of mid-age, with primary vocational education, and a high share is not employed. Interestingly, the number of returnees applying for unemployment benefits in Poland doubled over 2008-2009, suggesting that returning "into benefits" may be one of the strategies of coping with the crisis. However, most of the interviewed Polish migrants in the UK did not intend to return due to the crisis, with the main reasons for return in this case also being familyrelated.

Useful insights into the situation of return migrants can also be gained from the receiving countries' perspective. Deterioration of the Irish economy and a sharp increase in unemployment during the crisis has mostly affected industries and sectors with large concentrations of migrants from the new member states (NMS), such as construction, agriculture, wholesale and retail trade (see among others Barrett and Kelly, 2012; Papademetriou et al., 2010; Koehler et al., 2010 for the analysis of the Irish situation). Consequently, migrants from the new EU countries have experienced the largest increase in unemployment. Moreover, controlling for other socio-economic characteristics, this appears to be the only immigrant group more likely to be employed compared to natives and the only one whose employment prospects were negatively affected by the downturn, particularly for men (Barrett and Kelly, 2012). The large increase in immigrants' benefits claims 
during a recession was also documented for Ireland, with immigrants from the new member states being the largest group. As a result of the deteriorating economy, outflows of migrants from the new EU members from Ireland have increased. In contrast, the existing evidence to date suggests no significant rise in unemployment in the UK only for migrants from the new member states, while less educated, younger immigrants, those from poor countries, non-English speaking and ethnic minorities have generally faced an increase in unemployment (Papademetriou et al., 2010; Koehler et al., 2010). An increase in out migration in the UK started in 2008, which was the largest for the NMS migrants, however it fell in 2009. The situation was somewhat different in Spain. Despite the sharp increase in unemployment, especially in construction and for immigrants from Asia and Africa, immigration from the EU2 countries and particularly Romania did not decrease (at least until 2009), although Spain experienced a slow-down in overall immigration (Papademetriou et al., 2010; Koehler et al., 2010). In fact, these trends may have contributed to the re-introduction of the restrictions on free movement for the EU2 countries in July 2011.

In Germany, the crisis hit companies with relatively highly-qualified workers, in particular export-oriented and skill-intensive manufacturing (Rinne and Zimmermann, 2012; Kim, 2010; Papademetriou et al., 2010; Koehler et al., 2010) with lean labour cost structures. Job losses were rather moderate, since crisis-affected companies used time-accounts and labour hording supported by government-sponsored reduction in working hours as strong measures of internal flexibility. As a result, there was almost no increase in unemployment for migrants in Germany. Regarding postenlargement migration, immigration from the EU10 countries continued to increase.

Overall, emerging empirical studies do not suggest massive return migration during the crisis, especially if home countries are affected relatively more by the crisis. Moreover, some migrants may have chosen to migrate onwards to other destinations less affected by the recession (such as Norway). There is also some evidence from receiving countries, in particular the UK and Ireland that migrants from the EU emigrated in larger numbers than non-EU migrants, despite unemployment often being higher in the latter group, reflecting the role of restrictive migration policies (Koehler et al, 2010). Most importantly, the remaining transitional arrangements for the EU2 migrants may actually backfire, since these migrants may chose to remain in the host country after becoming unemployed due to uncertainty about the possibility to re-enter the destination country in the future (Koehler et al, 2010; Holland et al, 2010). 


\section{How large is return migration in the new member states?}

Return migration is difficult to measure, and making cross-country comparisons is even more complicated. We start with documenting immigration into the UK and Ireland, two countries that have attracted a substantial proportion of immigrants from the new EU member states. As seen from Figure 1, there was a slowdown in immigration to these countries during the crisis, however, while immigration continued to decline in Ireland, the trend in the UK was reversed in 2009, with immigration from the EU8 and EU2 countries starting to increase again. Moreover, in Ireland, immigration from all NMS (apart from Romania) declined, while in the UK it has increased particularly from Lithuania and Latvia (with a slowdown in 2011) and has even surpassed their post-accession peaks.

$<$ Insert Figure 1 here $>$

Turning now to the outmigration, Figure 2 shows the outflows of EU10 nationals from the EU15 and Norway over 2004-2010, based on the data from the OECD International Migration Database. There is some heterogeneity across countries, as outflows from all EU15 countries have increased for Bulgaria, Latvia and Lithuania, while they slowed-down or decreased for the remainder of the new EU members during the crisis. However, it is important to note that these outflows do not necessarily reflect return migration, since it is not known where these migrants went to. Moreover, increased outflows may be also a result of the increased inflows and onward migration.

\section{$<$ Insert Figure 2 here $>$}

To document the return migration, we now turn to the sending countries data, plotting the proportion of returnees in the population aged 24-65 in Figure 3. We employ two datasets containing information on return migrants, specifically the European Social Survey (ESS) rounds 4 and 5 for the years 2008 and 2010 and the Eurobarometer EB73-3 for March-April 2010. In the ESS data, returnees are defined as persons who were born in the country and spent at least 6 months working abroad over the last 10 years before returning. In the Eurobarometer data, it is possible to distinguish between return labour migrants, students who went to study abroad and came back, and other returnees. For comparative purpose, we retain return labour migrants who were born in the country and have worked (including volunteering and traineeships) for at least three consecutive months in a country other than their country of birth. Employing these "stock" definitions and first considering the ESS data, suggests that the share of returnees has increased over the two years in Bulgaria, Hungary and Poland, and declined in the Czech Republic, Estonia, Slovenia and Slovakia. As expected, the proportion of returnees is larger in all countries using the Eurobarometer data 
(apart from the Czech Republic, where the difference is negligible), which is attributable to several factors. First, since the duration of stay abroad is shorter (3 months vs. 6 months) it is thus more likely to include also seasonal workers. Second, the time horizon over which migration and return happens is not limited in the Eurobarometer dataset (it is 10 years in the ESS). The proportions of returnees in 2010 thus range from around 3\% in Slovenia to more than 10\% in Estonia and Poland if using the ESS data, and from around 6\% in the Czech Republic to around 18\% in Lithuania and16\% in Slovakia if using the Eurobarometer data (see Figure 3).

$<$ Insert Figure 3 here $>$

Overall, despite return migration being inherently affected by a substantial differences in measurement concepts, the available cross-country data suggests that some heterogeneity exists. On aggregate, there was a slow-down in inflows of the EU8 and EU2 countries in the UK and Ireland. However, the trend in the UK was reversed again in 2009. Moreover, while immigration from all new member states (apart for Romania) decreased in Ireland, in the UK it increased for a number of countries after 2009, reaching the highest ever levels for Lithuania and Latvia. On the other hand, the outflows from all EU15 countries have increased for Bulgaria, Latvia and Lithuania, also partially reflecting the increased inflows and potential onward migration, and have slowed-down or decreased for the rest of the new EU members during the crisis. Regarding the stock of return migrants and depending on definition, the Baltic states and also Slovakia and Poland are the countries with the largest proportions of returnees.

\section{Who is returning?}

This section draws on the data from the EU LFS for 2009 and 2010 to document the profile of a typical returnee who returns during the crisis. The data contain information on the country of residence one year before the survey, thus recording individuals who returned to their country over the last year. It is important to note, however, that these data are likely to underestimate the true level of return migration, since they capture only most recent returnees who came back over the last year and no longer-run estimates can be calculated.

Figure 4 depicts the economic activity of recent returnees one year before the survey, i.e. while abroad. The figure should be interpreted with caution, since the sample size is small for many countries, which may lead to unreliable estimates. Nevertheless, figure 4 shows that the majority of migrants were employed while abroad in all countries, apart from Slovenia where students constitute the largest group among returnees. The proportion of students who studied abroad a year ago and returned is also substantial in Estonia. On the other hand, the shares of returnees who were 
unemployed while abroad are largest in Bulgaria, Latvia, Romania and Slovenia, while the proportions of those inactive are largest in the Czech Republic, Latvia and Slovakia. These simple tabulations thus suggest that employment was by far the main activity abroad of recent returnees from all new member states (probably apart from Slovenia). ${ }^{5}$ Regarding the rest of the economic activities abroad, two scenarios become evident: in Estonia and Slovenia, returnees are also those individuals who went abroad to study and return after the completion of this goal, importantly suggesting a potential additional brain-gain for these countries; while in Bulgaria, Romania or Latvia, those who became unemployed also come back.

\section{$<$ Insert Figure 4 here $>$}

In this context, it is vitally important to understand whether those who return are the "best" or "worst" compared to stayers and also migrants, i.e. whether those who come back are "the worst of the best" or vice versa. Figure 5 shows such selection in terms of education for migrants in the EU15 countries, returnees from these countries, and stayers in the countries of origin. Bulgaria and Romania stand out as countries with the highest proportion of individuals with low educational attainment, and with higher shares among returnees than stayers in both countries (also higher than among migrants in Romania). The shares of the low-skilled, although smaller in magnitude, are also larger for returnees than stayers in Latvia, Hungary and Lithuania, and these shares are also relatively large among migrants in Latvia and Slovenia. On the other end of the skills distribution, skilled individuals are overrepresented among returnees in the Czech Republic, Hungary, and particularly Slovakia and Slovenia, suggesting a potential positive selection in terms of skills for returnees and the potential brain-gain for these countries. In Latvia, the shares of the highly educated among returnees are almost the same as among stayers, and both are substantially higher than for migrants. In contrast, although the proportions of highly skilled among stayers and migrants in Lithuania are similar, they are larger than for returnees.

$<$ Insert Figure 5 here $>$

To gain further insights into the determinants of return migration, we have undertaken the following modelling strategy. We again use the 2009 and 2010 annual EU LFS data to identify return migrants from the EU15 countries and current migrants who reside in the EU15 countries for at least one year as follows. In each of the new member states, we retrieve the returnees from the EU3 (the UK, Ireland and Sweden) and the EU12 (the rest of the old EU15) countries, i.e. those individuals who resided in the EU3 or EU12 countries one year before the survey. ${ }^{6}$ Subsequently, in

\footnotetext{
${ }^{5}$ Note, however, that this information is available for one year before the survey and an individual may still become unemployed or inactive in the months preceding the survey.

${ }^{6}$ Here we include only new EU members that joined in 2004, due to current transitional arrangements for Bulgaria and Romania. Moreover, due to the differences in transitional arrangements adopted with respect to the 2004 accession countries, we differentiate between those countries that opened up their labour markets immediately after the 2004
} 
each of the EU3 and EU12 countries we identify nationals from the new member states who are present in the old member states in 2009 and 2010, i.e. current migrants. We merge returnees back to their countries of residence one year before the survey to obtain a dataset on current migrants and returnees from the old EU15 countries. Finally, we only keep those migrants who report residing in the country for more than one year in our sample. Thus, our dependent variable is equal to one if an individual returns "home” from the EU15 countries between 2008 and 2009, or 2009 and 2010. Note that we assume that such characteristics as marital status and number of children did not change during one year in the analysis below, and use information on labour market status one year before the survey for both migrants and returnees. Table 1 shows the marginal effects from the probit regressions for the determinants of the return migration decision.

$<$ Insert Table 1 here $>$

This table indicates that males, single, older individuals, those with higher or middle education degrees and those without children are more likely to return, relative to respective migrants in the destination countries. The effect of age is attributable to the significant and negative impact for the returnees from the EU12 countries, suggesting that return is a subsequent stage in the migration decision as returnees are indeed older than migrants. The positive correlation with education is consistent with the theoretical implications that returnees, especially skilled ones, are expected to earn a premium after returning, and the observation that overqualified migrants from the new member states prefer to come back. Moreover, the effect is also economically significant and implies that having middle educational attainment increases the probability of return by 3.2 percentage points, while the probability increases by 3.5 percentage points for those with higher education (see column 2). Regarding policy implications, this effect suggests a potential brain circulation rather than brain drain for the new member states. In our model, having a family and children is associated with lower likelihood of returning, however, this may be due to families living abroad together with a migrant, or the larger responsibility that migrants with a family may feel with respect to finances. Regarding labour market status, although the sample size drops substantially, being inactive in the previous year appears to be positively correlated with the probability to return back to the country of origin, relative to the employed individuals, while no significant relation is found for the unemployed. Interestingly, in 2010 and relative to 2009 there is an increased likelihood of returns from the EU3 countries, but a decreased return probability for the EU12 countries, suggesting a potentially differential impact of the crisis on return migration between these two country groups. Finally, we have also experimented with including macro push-

enlargement (the UK, Ireland and Sweden) and the rest of the old EU15. Cyprus and Malta are excluded since no transitional arrangements were imposed for them. Luxembourg and Portugal are also excluded due to the specific nature of migrants to Luxembourg, and also because of the negligible number of returnees from these countries. 
factors that may affect return probability, particularly relative changes in GDP and the unemployment rate between 2008 and 2009 (relative to 2008) in the destination countries. When including both these factors, the increase in unemployment between 2008 and 2009 appears to push EU8 migrants to return from the EU3 countries, but not from the EU12. A higher (lower) growth rate in GDP per capita is associated with higher (lower) return migration from the EU3, which may reflect liquidity constraints or fears of a worse situation at home. In addition, the year effect becomes insignificant (at the 5\% level) after the inclusion of macroeconomic variables. However, it should be noted that apart from potential collinearity issues, the time span may be still too short to analyse the impact of the crisis on return migration; moreover, aggregate country-level unemployment rate and GDP per capita may not effectively capture the impact of the crisis on individual return migration decisions as local labour markets are probably more appropriate. ${ }^{7}$

Summarizing this section, our tabulations from the EU LFS data show that returnees were overwhelmingly employed while abroad. Several new EU members are also likely to benefit from positive selection of returnees in terms of skills and potential brain circulation, as the shares of highly educated among returnees are larger than among both stayers and migrants in the Czech Republic, Hungary, Slovakia and Slovenia. The brain circulation hypothesis is also confirmed by regressions as the probability to return is larger for individuals with higher educational attainments. Regression results also suggest that males, single, older individuals and those without children are more likely to return, ceteris paribus, relative to respective migrants in the destination countries.

\section{Is this the end of the story?}

In today's globalized world migrants can be increasingly characterised as "people constantly on the move”. Having experienced migration once, individuals face substantially lower costs for their potential subsequent moves, with improved language or established networks abroad also making such a move easier. On the other hand, the situation in the home country after returning may not be as expected since migrants may overestimate the potential premiums at home, or the overall situation may be disappointing. In addition, the human capital of individuals who worked in jobs below their qualifications may have depreciated over their stay abroad, thus resulting in a brainwaste. Therefore, it is likely that some returnees would move abroad again. ${ }^{8}$

\footnotetext{
${ }^{7}$ In addition, we have estimated the regressions for the probability to be a returnee relative to current work migrants using the EU LFS data for the EU10. With the exception of male and middle education category, the results were qualitatively identical (males and those with middle educational degree were less likely to be a returnee relative to current work migrants).

${ }^{8}$ For example, Constant and Zimmermann (2012) find very high probability of a repeated move back to Germany for return migrants from Germany, and that this probability is guided mainly by remittances and family considerations.
} 
To investigate the possibility of such repeat and circular migration for the new member states, we employ the Eurobarometer EB73_3 for March-April 2010. This dataset contains the following question regarding future migration intentions: "How likely do you think it is that you will move to another country within the next ten years, to live there?” Of particular relevance for our study is that it also contains information on past migration experiences, and particularly whether an individual had worked, studied or lived for another purpose in a country other than his/her own. ${ }^{9}$

As in any study of migration intentions, it is important to note that intentions may not necessarily correspond to actual realizations (Manski, 1990; Bertrand and Mullainathan, 2001), leading to an overestimated migration. However, several studies confirm that migration intentions are indeed closely related to the subsequent move (see also Zaiceva and Zimmermann, 2008 and the references therein). It is thus advisable to focus on the so-called "firm" migration intentions, actions such as learning a foreign language or applying for visas, which however are not available in our data. In addition, the time horizon in our data is ten years, which is quite large and may also lead to overestimated migration. To reduce this problem, we focus only on answers of "very likely" while presenting tabulations below for the likelihood to move abroad, which best approximate a "firm" willingness to move.

\section{$<$ Insert Figure 6 here $>$}

Figure 6 plots the replies to the question on migration intentions for both stayers and return labour migrants, i.e. those individuals who have worked in a foreign country for at least three consecutive months. Several interesting facts are evident from this figure. First, the proportion of those replying that they are "very likely" to move to another country is consistently larger among returnees than stayers in all new member states, suggesting the circular nature of the potential future East-West migration in Europe. Second, the largest proportion of those willing to emigrate, for both stayers and returnees, are in countries that were affected by the crisis - Latvia and Lithuania. Nearly $20 \%$ of return labour migrants in Lithuania and $25 \%$ of returnees in Latvia are "very likely" to move again within the next ten years. Third, apart from these two countries, the majority of returnees in the rest of the EU8 and EU2 countries do not plan to emigrate in the next ten years (“are not very likely” or "not at all likely”). Regarding the EU2, despite all remaining restrictions on mobility soon coming to an end, the proportions of respondents intending to move abroad are relatively small (around 9\% among returnees in Bulgaria and 5\% in Romania, and the figures are even lower for stayers - around 2\%).

\footnotetext{
${ }^{9}$ The exact wording is as follows: "You have worked (including volunteering and traineeships) for at least three consecutive months in another country than ours"; "You have attended school or studied for at least half an academic year in another country than ours"; "You have lived for reasons other than study or work for at least three consecutive months in another country than ours".
} 
For those willing to move abroad, the data also contains a question on a potential country of emigration, distinguishing between another EU country, another non-EU country, USA, Canada, Japan, Australia or New Zealand, or another country outside Europe. The majority of respondents, both returnees and stayers, reply being willing to move to another EU country in all new member states (apart from Slovenia). The shares of those intending to move to USA, Canada, Japan, Australia or New Zealand are substantial (close to or over 20\%) in Slovenia, Czech Republic, Slovakia and Hungary. However, these results should be interpreted with caution due to the small sample size for individuals intending to move abroad in a number of countries.

Finally, the results from probit regressions that control for demographic and socio-economic characteristics of individuals, such as gender, age, education, marital status, children, labour market status and country fixed effects, indicate that return labour migrants are significantly more likely to be willing to move abroad relative to stayers (not presented here due to space constraints). Moreover, the effect holds after having controlled for networks abroad (having friends or relatives abroad) and language knowledge. There is also some heterogeneity across countries, with the largest marginal effects for returnees, relative to Slovenia, being for Latvia and Lithuania, while the coefficients are not significant for Hungary and Romania (and only marginally significant for Czech Republic, Poland and Bulgaria).

Overall, the results from this section point towards a potential for repeat and circular migration in the post-enlargement Europe. Individuals with work experience abroad are more likely to move abroad again, relative to those without such experience, in the majority of the new EU member states, and most intend to move to another EU country.

\section{Conclusions}

Return migration is becoming increasingly important in post-enlargement Europe, and this chapter provides a systematic analysis of its emerging evidence. The ongoing economic crisis may have accelerated the returns of some of these migrants. However, since several new member states, particularly the Baltics, were hit relatively more by the crisis than several destination countries, return migration may be delayed.

Summarizing the findings from the literature and our own analysis, we find no evidence of “mass return”. Instead, while there is a slowdown in overall post-enlargement immigration into the two major destination countries, the UK and especially Ireland, immigration to the UK from the two Baltic countries has increased to unprecedented levels. There is also some evidence of increased outflows from the EU15 countries for several new member states, however, this may be a result of 
some migrants choosing to migrate onwards to other destinations less affected by the recession (such as Norway). Analysing return migration is inevitably affected by substantial measurement challenges, and making the cross-country comparisons is even more complicated, since data collection methods and definitions vary (stocks vs. flows, age of migrants, time spent abroad, etc.). Despite this major difficulty, we show that depending on definition, the Baltic states and also Slovakia and Poland are the countries with the largest proportions of returnees.

Regarding returnees' characteristics, we find that return migrants were overwhelmingly employed while abroad. In addition, simple tabulations suggest that several new EU member states are likely to benefit from the positive selection of returnees in terms of skills and potential brain circulation, as the shares of highly educated among returnees are larger than among both stayers and migrants in the Czech Republic, Hungary, Slovakia and Slovenia. The positive selection on education is also confirmed by regressions, as the probability to return is larger for individuals with middle and higher educational attainments. However, this result may also arise because overqualified individuals who were employed in jobs below their qualifications return disproportionally more. Furthermore, regression results suggest that males, single, older individuals and those without children are more likely to return, ceteris paribus, relative to respective migrants in the destination countries.

Returning home at times of trouble may not be the end of the story. We find that individuals with work experience abroad are more likely to move abroad again, relative to those without such experience, in the majority of the new EU member states, and most intend to move to another EU country. This result points towards an important potential repeat and circular migration in the postenlargement Europe.

Overall, enjoying free mobility (although still with some restrictions for the EU2 workers), post-enlargement migrants constitute a highly flexible and valuable resource that may act as "buffer" during the economic crisis. Potential repeat and circular migration is expected to alleviate the negative impacts of the crisis, leading to brain circulation rather than brain drain and a more efficient allocation of resources within the EU. Most importantly, remaining transitional arrangements for the EU2 migrants may actually backfire, since these migrants may chose to remain in the host country after becoming unemployed, due to uncertainty about the possibility to re-enter the destination country in the future. Altogether and keeping in mind potential brain circulation in the enlarged Europe, this suggests important implications for migration policy. 


\section{References}

Barcevičius, E. and D. Žvalionytė (2012). Užburtas Ratas? Lietuvos Gyventojų Grįžtamoji ir Pakartotinė Migracija (in Lithuanian). Public Policy and Management Institute. Vilnius.

Barrett, A. and E. Kelly (2012). The Impact of Ireland's Recession on the Labour Market Outcomes of its Immigrants. European Journal of Population, 28 (1), 91-111

Bertrand, M., and Mullainathan, S. (2001), Do People Mean What They Say? Implications for Subjective Survey Data, The American Economic Review 91 (2), 67-72.

Brücker, H., A. Damelang (2009), Labour Mobility within the EU in the Context of Enlargement and the Functioning of the Transitional Arrangements. Analysis of the Scale, Direction and Structure of Labour Mobility. Deliverable 2. IAB, Nürnberg.

Brücker, H. et al. (2009), Labour Mobility within the EU in the Context of Enlargement and the Functioning of the Transitional Arrangements. Final Report (IAB, CMR, fRDB, GEP, WIFO, wiiw), Nürnberg.

Constant, A. F. and K. F. Zimmermann (2012). The Dynamics of Repeat Migration: A Markov Chain Analysis. International Migration Review, 46 (2), 361-387.

Constant, A. F. and K. F. Zimmermann (2011), Circular and Repeat Migration: Counts of Exits and Years Away from the Host Country. Population Research and Policy

Review, 30 (4), 495-515.

Constant, A. F., O. Nottmeyer and K. F. Zimmermann (2012). The Economics of Circular Migration. IZA Discussion Paper No. 6940 (forthcoming 2013 in: Constant, A. F. and K. F. Zimmermann (eds.), International Handbook on the Economics of Migration, Edward Elgar).

Eurofound (2012). Labour mobility within the EU: The impact of return migration. European Foundation for the Improvement of Living and Working Conditions, Dublin, Ireland. 
European Commission (2008), The Impact of Free Movement of Workers in the Context of EU Enlargement, Report on the first phase (1 January 2007 - 31 December 2008) of the Transitional Arrangements set out in the 2005 Accession Treaty and as requested according to the Transitional Arrangements set out in the 2003 Accession Treaty. Communication from the Commission to the European Parliament, the Council, the European Economic and Social Committee and the Committee of the Regions. Brussels, 18 November 2008.

Hazans, M. (2008). Post-enlargement return migrants' earnings premium: Evidence from Latvia. Paper presented at EALE Conference in Amsterdam, September 2008.

Hazans, M. and K. Philips (2010). The Post-Enlargement Migration Experience in the Baltic Labor Markets. In: M. Kahanec and K. F. Zimmermann (eds), EU Labor Markets After Post-Enlargement Migration, Berlin - Heidelberg: Springer, 2009, 255-304

Holland,D., T. Fic, A. Rincon-Aznar, L. Stokes, P. Paluchowski (2011). Labour mobility within the EU - The impact of enlargement and the functioning of the transitional arrangements. Final Report. Study for the DG Employment, Social Affairs and Inclusion, European Commission. National Institute of Economic and Social Research, London.

Iara, A. (2008). Skill Diffusion by Temporary Migration? Returns to Western European Working Experience in the EU Accession Countries, WIIW Working Paper No. 46.

Kahanec, M. and K. F. Zimmermann (2010) (eds.) EU Labor Markets after Post-Enlargement Migration. Springer: Berlin, et al.

Kahanec M., A. Zaiceva and K. F. Zimmermann (2010). Lessons from Migration after EU Enlargement. In: M. Kahanec and K. F. Zimmermann (eds.), EU Labor Markets after PostEnlargement Migration, Springer: Berlin, et al., pp. 3-45.

Kim, A. (2010). Foreign Labour Migration and the Economic Crisis in the EU: Ongoing and Remaining Issues of the Migrant Workforce in Germany. IZA Discussion Paper No. 5134.

Koehler, J., F. Laczko, C. Aghazarm, J. Schad (2010). Migration and the Economic Crisis in the European Union: Implications for Policy. IOM Thematic Study, IOM, Brussels. 
Manski, C.F. (1990). The Use of Intentions Data to Predict Behavior: A Best-Case Analysis, Journal of American Statistical Association, 85, 934-40.

Martin, R. and D. Radu (2009). Return Migration: The Experience of Eastern Europe. Paper presented at the XXIV National Conference of Labour Economics at the Italian Association of Labour Economists, Sassari.

Mayr, K. and G. Peri (2009). Brain Drain and Brain Return: Theory and Application to EasterWestern Europe. The B. E. Journal of Economic Analysis \& Policy, Berkeley Electronic Press, vol. 9 (1), p. 49.

Papademetriou, D. G., M. Sumption, A. Terrazas with C. Burkert, S. Loyal, and R. Ferrero-Turrion (2010). Migration and Immigrants Two Years After the Financial Collapse: Where Do We Stand? Washington, DC: Migration Policy Institute.

Pollard, N., M. Latorre, D. Sriskandarajah (2008), Floodgates or Turnstiles? Post-EU Enlargement Migration Flows to (and from) the UK. Institute for Public Policy Research, London.

Pungas, E., Toomet, O. and T. Tammaru (2012). Are Better Educated Migrants Returning? Evidence from Multidimensional Educational Data. Norface Discussion Paper No. 2012018.

Re-Turn (2012). Comparative Report on Re-Migration Trends in Central Europe. Re-Turn Consortium, Leibniz Institute for Regional Geography, Leipzig.

Rinne, U. and K. F. Zimmermann (2012). Another Economic Miracle? The German Labor Market and the Great Recession. IZA Journal of Labor Policy, 2012, 1, Article 3.

Zaiceva, A. and K. F. Zimmermann (2008). Scale, Diversity, and Determinants of Labour Migration in Europe. Oxford Review of Economic Policy, 24 (3), 428-452 
Figure 1: Immigration to the UK and Ireland of the EU8 and EU2 nationals
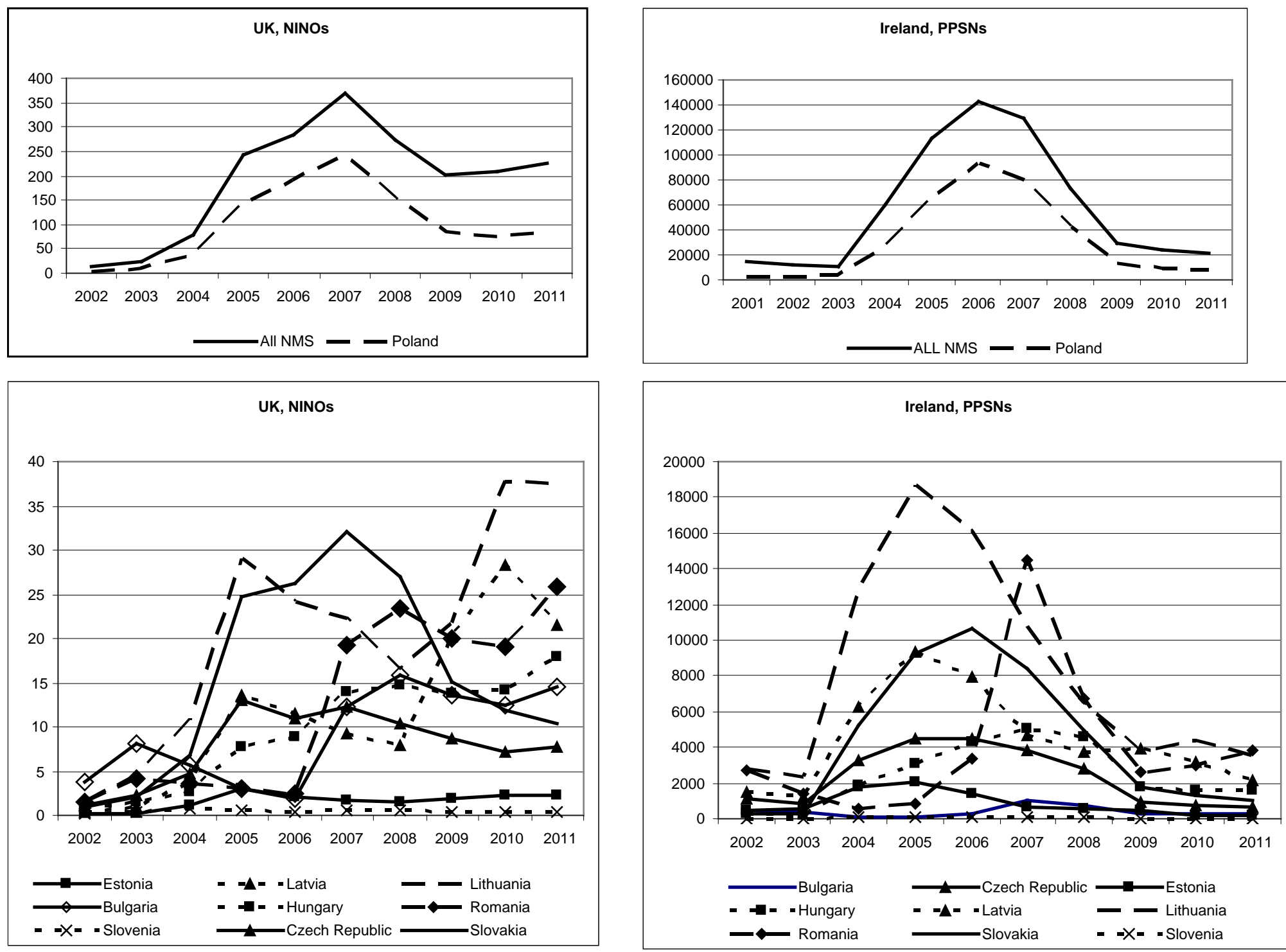

Source: http://statistics.dwp.gov.uk/asd/asd1/niall/index.php?page=nino_allocation and http://www.welfare.ie/EN/Topics/PPSN/Pages/ppsstat.aspx

Notes: NINOs refer to National Insurance Numbers, data are in thousands. PPSNs refer to Personal Public Service Numbers. 
Figure 2: Outflows of the EU10 nationals from the EU15 and Norway, 2004-2010 (in thousands)
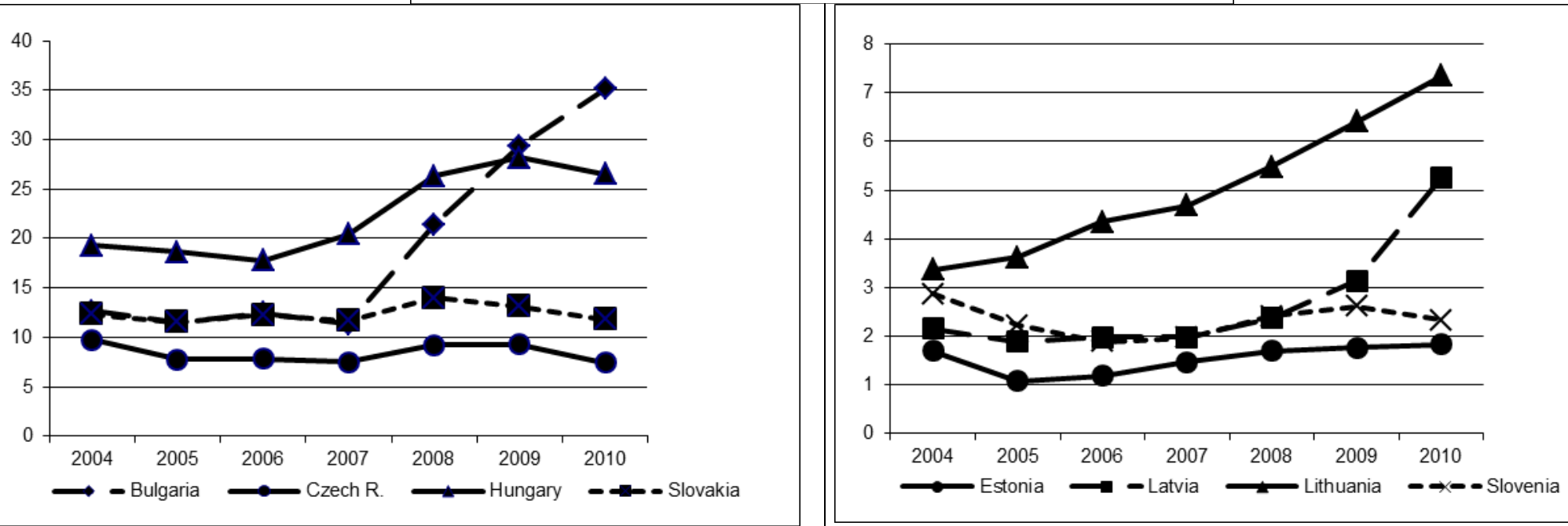

Source: OECD International Migration Database, Outflows of foreign population. OECDStats.

Notes: Data are missing for outflows from France, Greece, Ireland, Portugal, and generally Belgium and the UK. For Italy data for 2010 are misssing.PL: with UK for 2007-2010; with Belgium for 2004-2009; BG: with Belgium for 2008, 2009; CZ: with Belgium for 2008, 2009; HU: with Belgium for 2008, 2009; LT: with Belgium for 2008, 2009; RO: with Belgium for 2008, 2009; SK: with Belgium for 2008, 2009; SI: with Netherlands in 2009, 2010. 
Figure 3: Share of return labour migrants in the population aged 24-65, 2008 and 2010

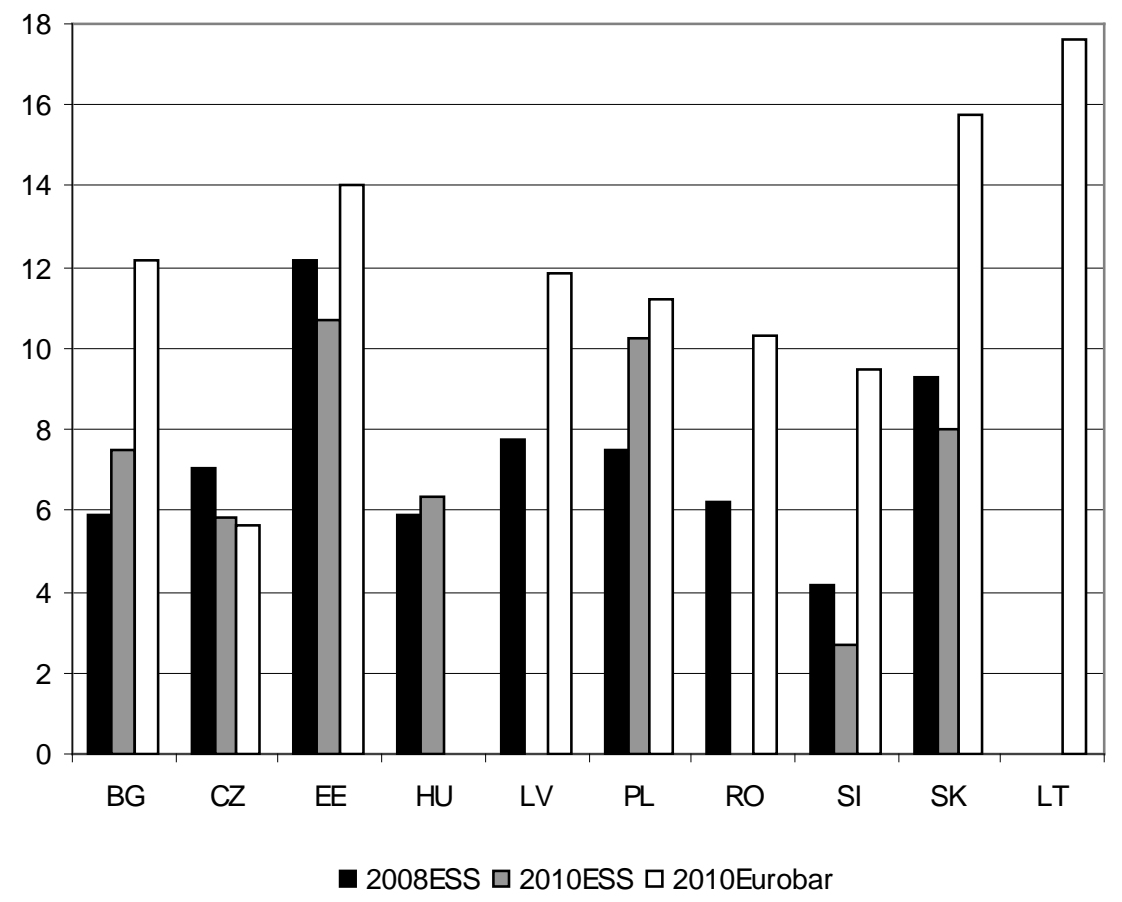

Source: European Social Survey, rounds 4 and 5; Eurobarometer EB73-3, March-April 2010 Notes: In the ESS data, return migrants are persons born in the country who spent at least 6 months working abroad over the last 10 years and returned. In the Eurobarometer data, return migrants are persons born in the country who have worked (including volunteering and traineeships) for at least three consecutive months in a country other than their country of birth. Estimates are weighted averages. 




Source: EU Labour Force Survey 2009-2010.

Notes: *stands for less reliable estimates due to the negligible sample size of the returnees from the EU15. A recent returnee is a national of the country who resided in a country other than his/her own one year before survey. Estimates are weighted averages. 
Figure 5: Distribution of education categories for stayers, migrants in and returnees from the EU15, age 25-64

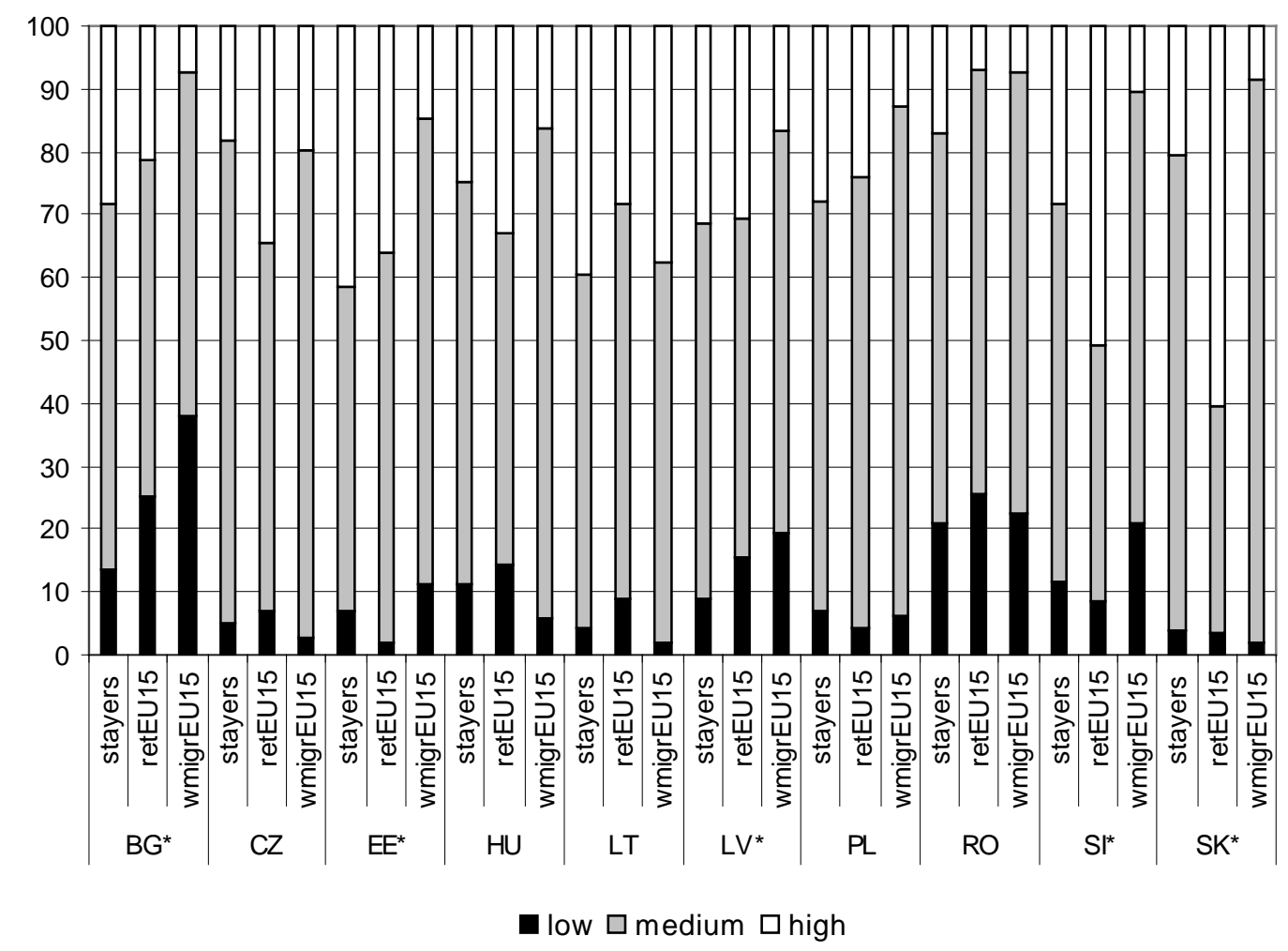

Source: EU Labour Force Survey 2009-2010.

Notes: *stands for less reliable estimates due to the negligible sample size of the returnees from the EU15. A recent returnee is a national of the country who resided in a country other than his/her country one year before survey. A migrant is a national of the country whose current country of place of work is not his/her country. Estimates are weighted averages. 
Figure 6: Migration intentions of stayers and returnees in the EU10

"How likely do you think it is that you will move to another country within the next ten years, to live there?"

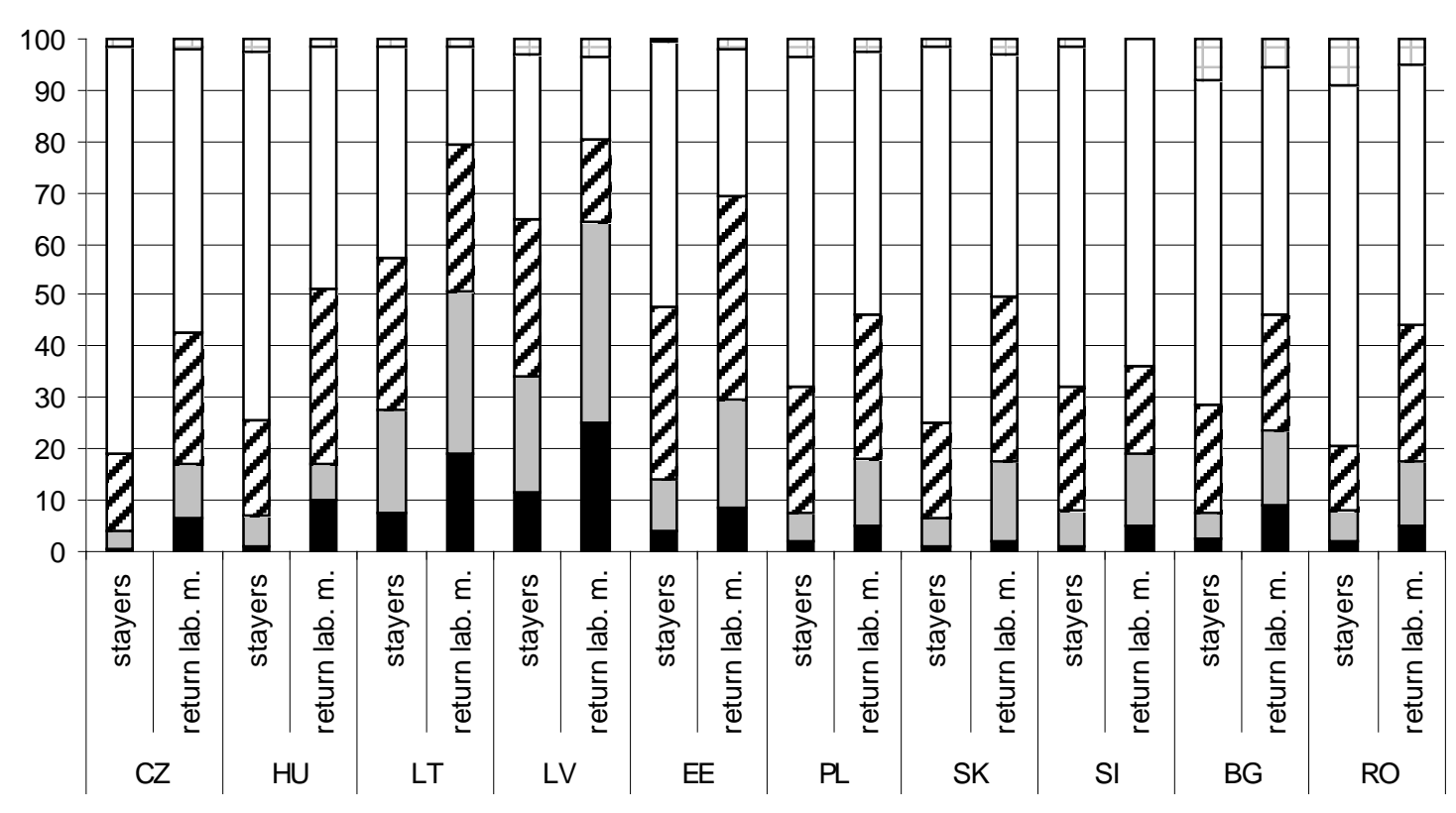

$\square$ Very likely $\square$ Fairly likely $\square$ Not very likely $\square$ Not at all likely $\square$ Don't know

Source: Eurobarometer EB73-3, March-April 2010.

Notes: Simple averages. Age: 15-64. Return labour migrants are those who replied "Yes" to the question: "You have worked (including volunteering and traineeships) for at least three consecutive months in another country than yours" 
Table 1: Determinants of return migration from the EU15 for the EU8 nationals, Marginal effects from Probit

\begin{tabular}{|c|c|c|c|c|c|c|}
\hline & $\begin{array}{c}(1) \\
\text { EU15 }\end{array}$ & $\begin{array}{c}(2) \\
\text { EU15 }\end{array}$ & $\begin{array}{c}(3) \\
\text { EU15 }\end{array}$ & $\begin{array}{c}(4) \\
\text { EU15 }\end{array}$ & $\begin{array}{c}\text { (5) } \\
\text { EU3 }\end{array}$ & $\begin{array}{c}(6) \\
\text { EU12 }\end{array}$ \\
\hline Male & $\begin{array}{c}0.021 * * * \\
(0.003)\end{array}$ & $\begin{array}{c}0.017 * * * \\
(0.002)\end{array}$ & $\begin{array}{c}0.014^{* * *} \\
(0.002)\end{array}$ & $\begin{array}{c}0.038^{* * *} \\
(0.005)\end{array}$ & $\begin{array}{c}0.011^{* * *} \\
(0.002)\end{array}$ & $\begin{array}{c}0.031^{* * *} \\
(0.005)\end{array}$ \\
\hline Younger than 45 & $\begin{array}{c}-0.015 * * * \\
(0.005)\end{array}$ & $\begin{array}{c}-0.009 * * * \\
(0.003)\end{array}$ & $\begin{array}{c}-0.009 * * \\
(0.004)\end{array}$ & $\begin{array}{c}-0.023 * * * \\
(0.007)\end{array}$ & $\begin{array}{c}-0.006 \\
(0.005)\end{array}$ & $\begin{array}{c}-0.012^{* *} \\
(0.005)\end{array}$ \\
\hline Separated & $\begin{array}{c}-0.031^{* * *} \\
(0.004)\end{array}$ & $\begin{array}{c}-0.024 * * * \\
(0.002)\end{array}$ & $\begin{array}{c}-0.023 * * * \\
(0.002)\end{array}$ & $\begin{array}{c}-0.052 * * * \\
(0.004)\end{array}$ & $\begin{array}{c}-0.021^{* * *} \\
(0.003)\end{array}$ & $\begin{array}{c}-0.030 * * * \\
(0.004)\end{array}$ \\
\hline Married & $\begin{array}{c}-0.034 * * * \\
(0.003)\end{array}$ & $\begin{array}{c}-0.026 * * * \\
(0.002)\end{array}$ & $\begin{array}{c}-0.024 * * * \\
(0.002)\end{array}$ & $\begin{array}{c}-0.059 * * * \\
(0.005)\end{array}$ & $\begin{array}{c}-0.023 * * * \\
(0.002)\end{array}$ & $\begin{array}{c}-0.034^{* * *} \\
(0.004)\end{array}$ \\
\hline Mid. education & $\begin{array}{c}0.048 * * * \\
(0.004)\end{array}$ & $\begin{array}{c}0.032 * * * \\
(0.003)\end{array}$ & $\begin{array}{c}0.030 * * * \\
(0.003)\end{array}$ & $\begin{array}{c}0.063 * * * \\
(0.006)\end{array}$ & $\begin{array}{c}0.026 * * * \\
(0.004)\end{array}$ & $\begin{array}{c}0.044 * * * \\
(0.005)\end{array}$ \\
\hline Higher education & $\begin{array}{c}0.031 * * * \\
(0.006)\end{array}$ & $\begin{array}{c}0.035^{* * *} \\
(0.005)\end{array}$ & $\begin{array}{c}0.036^{* * *} \\
(0.006)\end{array}$ & $\begin{array}{c}0.090^{* * *} \\
(0.012)\end{array}$ & $\begin{array}{c}0.027^{* * *} \\
(0.005)\end{array}$ & $\begin{array}{c}0.053 * * * \\
(0.012)\end{array}$ \\
\hline Year 2010 & $\begin{array}{c}-0.005^{*} \\
(0.003)\end{array}$ & $\begin{array}{c}0.000 \\
(0.002)\end{array}$ & $\begin{array}{c}0.001 \\
(0.002)\end{array}$ & $\begin{array}{c}-0.015 * * * \\
(0.004)\end{array}$ & $\begin{array}{c}0.007^{* * *} \\
(0.002)\end{array}$ & $\begin{array}{c}-0.013^{* * *} \\
(0.004)\end{array}$ \\
\hline Nr. of children & & & $\begin{array}{c}-0.004 * * * \\
(0.002)\end{array}$ & & & \\
\hline Unempl. 1 year ago & & & & $\begin{array}{c}-0.003 \\
(0.009)\end{array}$ & & \\
\hline Inactive 1 year ago & & & & $\begin{array}{c}0.018 * * * \\
(0.006)\end{array}$ & & \\
\hline Country dummies & No & Yes & Yes & Yes & Yes & Yes \\
\hline Observations & 23790 & 23790 & 21830 & 10617 & 16247 & 7543 \\
\hline
\end{tabular}

Notes: Standard errors are clustered by country and are reported in parentheses. * significant at $10 \%$; ** significant at $5 \%$; *** significant at 1\%. Reference country: Ireland in columns (2), (3) and (5); UK - in column (4); Germany - in column (6). Reference categories: female, older than 45 years, single, lower educational level, year 2009, employed one year before the survey Portugal and Luxembourg are excluded due to the negligible number of returnees from these countries 